\title{
Determination of SpontaneousIgnition of SSSR and Fish Meal duringTransport and Storage
}

\author{
Naoharu Murasawa \\ Faculty of Risk and Crisis Management, Chiba Institute of Science 3 \\ Shiomi-Cho, Choshi 288-0025, Japan \\ E-mail: rd10r01@cis.ac.jp \\ Hiroshi Koseki \\ National Research Institute of Fire and Disaster 4-35-3 \\ Jindaiji-Higashimachi, Chofu 182-8508, Japan \\ Tel: 81-422-44-8331 E-mail: koseki@fri.go.jp \\ Yusaku Iwata \\ National Research Institute of Fire and Disaster 4-35-3 \\ Jindaiji-Higashimachi, Chofu 182-8508, Japan \\ Tel: 81-422-44-8331_E-mail: iwata@fri.go.jp \\ Yasuhito Shibata \\ Fire Research Laboratory, Nagoya City Fire Bureau2280-12 \\ Nagahazama, Shimoshidami, Moriyama-ku, Nagoya 463-0003, Japan \\ Tel: 81-52-736-2201 E-mail: 00kenkyu@fd.city.nagoya.lg.jp
}

Received: October 14, 2011

Accepted: October 28, $2011 \quad$ Published: February 1, 2012

doi:10.5539/jfr.v1n 1 p320

URL: http://dx.doi.org/10.5539/jfr.v1n1p320

\begin{abstract}
Trends of wastes-recycle generated from the food industry have started to appear. There are some cases in which food wastes or products manufactured by recycling have generated heat at the low temperatures because of fermentation or oxidization, resulting in spontaneous ignition during transport or storage. In addition, the case in which depletion of oxygen in the storage area owing to fermentation and oxygen deprivation causing death of workers has been reported.In this study, Soy sauce squeezing residue produced during the brewing of soy sauce and Fish meal produced during the processing of Fish residue were considered. Hazard assessment tests focusing on heat analysis were conducted, aiming to acquire basic data for recurrence prevention.
\end{abstract}

Keywords: Soy sauce squeezing residue (SSSR), Fish meal, Fermentation, Spontaneous ignition, Thermal analysis

\section{Introduction}

Recently, there has been an increase in the trend to reduce waste generation as much as possible and carry out recycling and energy recovery to construct a recycling-oriented society (Hoshino, Iwata \& Koseki, 2007; Shibata, Koseki \& Shimizu). Even certain wastes that are difficult to recycle can be effectively used to the maximum by collecting heat energy generated by incineration in the form of electricity or steam. Examples of products manufactured by recycling wastes include wood chips manufactured from scrap wood (Li, Koseki \& Momota, 2006), refuse-derived fuel (RDF) manufactured from household-generated waste ( $\mathrm{Fu}, 2005 ; \mathrm{Li}, 2008)$, refuse paper and plastic fuel (RPF) manufactured from waste paper and plastic and sludge fuel manufactured from 
sewage sludge (Li, 2008). Existing studies have shown that fermentation may lead to heat generation and fire (Koseki, 2011).

Soy sauce and Fish play vital roles in the Japanese food culture. Sushi, which uses both soy sauce and Fish, is also a very popular Japanese food. Even in other countries, soy sauce and Fish are representative of the Japanese food culture. Soy sauce squeezing residue (SSSR) and Fish meal are waste products generated from their respective food industries. SSSR is nutritious and is used as feed in animal husbandry and as incinerator fuel. Fish meal is used as fertilizer and pet food. However, there have been cases in which SSSR and Fish meal have caught fire during transport or storage because of spontaneous ignition and oxygen deprivation in the storage area has led to death of workers. Fermentation is believed to be responsible for such hazards that involve the aforementioned wood chips or RDF.Because the composition of waste material is not fixed, simulation experiments are difficult and the investigation of the causes of hazards is even more difficult. When investigating the causes, the identification of the causes of and scenarios for heat generation in the early stages of fires, accidents and their processes is considerably difficult. In this study, various heat analysis methods were applied, and hazard assessment tests were conducted by focusing on SSSR and Fish meal to examine the causes and scenarios leading to spontaneous ignition and oxygen deprivation.

\section{Experiments}

\subsection{Samples}

A large amount of SSSRare produced when moromi (unrefined soy sauce) is compressed to extract raw soy sauce. When first produced, SSSR is plate shaped, but it is then finely ground for storage and processing (Figure 1). Fish meal refers to the crushed powder obtained by boiling residual Fish substances, removing water and oil from this residue by using a presser and then finally drying the remaining solid with hot air or steam (Figure 2).

To ascertain the effects of fermentation, samples were sterilized for seventeen hoursusing ethylene oxide gas (EOG). To ascertain the influence of fat and oil, samples were defatted for six hours using diethyl ether as solvent.

\subsection{Thermo gravimetric differential thermal analysis}

A thermo gravimetric differential thermal analysis (TG-DTA) system (RigakuThermoplus TG 8120) was used to study the overall thermal characteristics of the samples. An aluminium open container $(0.05 \mathrm{ml})$ was used as sample container. Figure 3 shows the schematic of TG-DTA. We studied the thermal characteristics of $\sim 20 \mathrm{mg}$ samples by heating them from room temperature to $600{ }^{\circ} \mathrm{C}$ at a rate of $2 \mathrm{~K} / \mathrm{min}$ in air circulating at a speed of $150 \mathrm{ml} / \mathrm{min}$.

\subsection{Calorimetry}

A Calvet calorimeter (Setaram C80, France) was used for additional thermal testing. The C80 (Figure 4) is a twin type highly sensitive heat-flux calorimeter. It can reduce the effects of evaporation of water contained in the sample by using a high-pressure closed vessel $(8 \mathrm{ml})$ and can make measurements from room temperature to $100^{\circ} \mathrm{C}$, which is a difficult temperature range to measure by TG-DTA. For these measurements, the temperature was increased at $0.1 \mathrm{~K} / \mathrm{min}$. A $1500 \mathrm{mg}$ sample in a closed stainless steel vessel raised the temperature in the vessel from room temperature to $300{ }^{\circ} \mathrm{C}$ under a limited-air atmosphere.

\subsection{Gas chromatography}

To study gas emission during storage, an about $50 \mathrm{~g}$ sample was placed in a $1 \mathrm{~L}$ glass bottle that was sealed airtight and placed in a thermostat oven. The gas produced was collected (Figure 5) and measured by gas chromatography (Shimadzu, GC-14B) using standard gas (CO: $0.0500 \%, \mathrm{C}_{2} \mathrm{H}_{6}: 0.995 \%, \mathrm{H}_{2}: 0.097 \%, \mathrm{CO}_{2}$ : $0.996 \%, \mathrm{CH}_{4}: 0.987 \%$ ) for calibration and a thermal conductivity detector $\left(\mathrm{TCD}, 200{ }^{\circ} \mathrm{C}\right.$, sensitivity was $50 \mathrm{~mA}$, carrier gas was Ar at $20 \mathrm{ml} / \mathrm{min})$. The column temperature was ranged from $40{ }^{\circ} \mathrm{C}(6 \mathrm{~min}$ hold $)$ to $80{ }^{\circ} \mathrm{C}(12 \mathrm{~min}$ hold) to $150{ }^{\circ} \mathrm{C}(10 \mathrm{~min}$ hold $)$ and changed at a rate of $40{ }^{\circ} \mathrm{C} / \mathrm{min}$. Moreover, an air cylinder $\left(\mathrm{O}_{2}: 21 \%, \mathrm{~N}_{2}: 79 \%\right)$ was used as the standard gas for measurement of $\mathrm{O}_{2}$ and $\mathrm{N}_{2}$. For these measurements, we used a TCD $\left(200{ }^{\circ} \mathrm{C}\right.$, $20 \mathrm{ml} / \mathrm{min}$ Ar carrier gas, $30 \mathrm{~mA}$ sensitivity) with the isothermal column temperature maintained at $30^{\circ} \mathrm{C}$.

\section{Results and Discussion}

\subsection{Thermo gravimetric differential thermal analysis}

The TG-DTA results with temperature increase rate of $2 \mathrm{~K} / \mathrm{min}$ are shown in Figure 6 , and a summary of the mass loss at $100{ }^{\circ} \mathrm{C}$ and the heat generation onset temperature is shown in Table 1 . The heat generation onset temperature is the temperature at which the DTA curve shifted by $0.1 \mu \mathrm{V}(0.01 \mathrm{~K})$ in the heat generation direction from the baseline where the DTA curve is constant. The horizontal axis shows the sample temperature and the 
vertical axis shows the TG (weight change) and DTA (thermal behaviour). The bottom of the TG curve indicates weight decrease and the top indicates weight increase. For the DTA curve, the downward direction indicates an endothermic reaction and the upward direction indicates an exothermic reaction. The thermal decomposition of SSSR and Fish meal is divided into three phases.

Because of dehydration in the SSSR, the TG curve indicates a weight decrease from room temperature to $100{ }^{\circ} \mathrm{C}$. These results show that about $26 \%$ of the SSSR water content was consumed during this period. Weight decrease and combustion due to decomposition of organic components was observed from 180 to $380{ }^{\circ} \mathrm{C}$. During this phase, the weight decreased by about $70 \%$. In the next-higher temperature range, we observed weight decrease and heat generation due to decomposition and combustion of carbide, until about $10 \%$ residue. From room temperature to $100{ }^{\circ} \mathrm{C}$, dehydration in Fish meal led to about $7.8 \%$ mass loss.

A more moderate rate of mass loss was observed for Fish meal compared with that observed in SSSR, which resulted in a smaller overall heat-generation peak for Fish meal compared with SSSR. Thus, SSSR exhibited a more active heat-generation reaction. However, a larger amount of residue remained for Fish meal. In the DTA curve, the shift in the heat generation direction began at $172.9^{\circ} \mathrm{C}$ for SSSR and around at $187.3{ }^{\circ} \mathrm{C}$ for Fish meal. Self-heat generation is assumed to begin at near these temperatures, and the fire occured.

\subsection{Calorimetry}

The results of increasing the temperature rate of SSSR and Fish meal to $0.1 \mathrm{~K} / \mathrm{min}$ are shown in Figsure 7 and 8 . In addition, the heat-generation-onset temperature and the total heat generated between room temperature and $100{ }^{\circ} \mathrm{C}$ is summarised in Tables 2 and 3 . The heat-generation-onset temperature is defined as the temperature at which the heat generation direction given by the TG-DTA curve first starts to shift after beginning the measurement at room temperature. These results indicate that a more detailed thermal characterisation would result from using a closed pressure-resistant cell and increasing the sample volume than by TG-DTA measurements.

The heat-generation onset in unprocessed SSSR and Fish meal occurred at the temperatures below $30{ }^{\circ} \mathrm{C}$. These results show that a fire is likely caused with spontaneous ignition when conditions are conducive to heat accumulation even if the materials were stored near room temperature. Furthermore, the likelihood of reaching the self-heat generation temperatures is high when the rate of heat generated by fermentation and oxidation exceeds the rate of heat externally released.

No heat generation was observed for EOG treated and sterilized SSSR and for SSSR defatted by diethyl ether between room temperature and $50{ }^{\circ} \mathrm{C}$. For the defatted case, we attribute this result to the diminish of fermentation microorganisms during the defatting process.

In refard to EOG treated and sterilized Fish meal, the heat generation onset temperature was only slightly higher than that of untreated Fish meal. For defatted Fish meal, the heat generation onset temperature was higher than those of untreated and EOG-treated Fish meal. By comparing the results of SSSR and Fish meal at the beginning of the heat-generation period, we conclude that heat generation by SSSR is largely caused by microbial fermentation and heat generation by Fish meal, although influenced by fermentation, is affected more by fat oxidation. We attribute the heat generation observed from 50 to $100^{\circ} \mathrm{C}$ to oxidation of residual fat that could not be defatted under the present conditions and to oxidation of other components.

\subsection{Gas chromatography}

The results of the $\mathrm{C} 80$ test indicate that, between room temperature and $50{ }^{\circ} \mathrm{C}$, fermentation more strongly affects temperature increase in SSSR than in Fish meal. To further study the effect of gas generation and fermentation for storage at $50{ }^{\circ} \mathrm{C}$, the sample storage temperature was changed from 5 to $50{ }^{\circ} \mathrm{C}$, and the amount of gas generated was collected and measured. Since the water content is assumed to affect fermentation, a sample with $20 \%$ added distilled water was also measured.

Results for SSSR are shown in Table 4 and those for Fish meal are shown in Table 5. Figure 9-12show the oxygen concentration and carbon dioxide concentration against storage temperature based on the data of Tables 4 and 5. These results show that most of the gas generated from SSSR during storage was carbon dioxide. In addition, we found that Fish meal generates combustible gases, such as hydrogen and carbon monoxide, in addition to carbon dioxide.

Regarding SSSR, we found that carbon dioxide can be generated in amounts that can affect the human body (Wada, 2006), and the amount of carbon dioxide generated increased with the addition of moisture. Generation of a large amount of carbon dioxide was observed at temperatures below $25^{\circ} \mathrm{C}$, even when moisture was not added These results show that ventilation and the humidity level should be carefully monitored, even for storage 
in a refrigerated space.

Regarding Fish meal, nearly no carbon dioxide was generated at or below $25^{\circ} \mathrm{C}$, even when moisture was added. However, above $25^{\circ} \mathrm{C}$, we found a rapid reduction of oxygen concentration and the generation of large amounts of carbon dioxide for samples with added moisture. For both SSSR and Fish meal, the amount of generated carbon dioxide increased with temperature between 5 and $30{ }^{\circ} \mathrm{C}$ but, at higher temperatures, the amount of carbon dioxide gradually decreased with increasing temperature. We attribute this result to more active fermentation in SSSR than in Fish meal, which is the same as for the C80 test. Moreover, we found that, when stored around $30{ }^{\circ} \mathrm{C}$, SSSR and Fish meal primarily generated carbon dioxide, which reached doses lethal to humans.

\section{Conclusion}

1) We found that SSSR contained about $26 \%$ moisture, whereas Fish meal contained about $8 \%$. Thermal decomposition of both SSSR and Fish meal occurred in three separate phases, but overall, SSSR exhibited a more active heat generation reaction. Moreover, the temperature at which start of self- heat generation was at about $173{ }^{\circ} \mathrm{C}$ in SSSR and at about $187^{\circ} \mathrm{C}$ in Fish meal. Fermentation and oxidation lead to an increase in temperature and, once the temperature reaches this level, self-heat generation begins, which can lead to fire due to spontaneous ignition.

2) The onset of heat generation was observed in both SSSR and Fish meal at $30^{\circ} \mathrm{C}$ or below. Between room temperature and $50^{\circ} \mathrm{C}$, we found that heat generation in SSSR was more affected by fermentation, whereas heat generation in Fish meal was more influenced by fat oxidation. Thus, storage of these materials under conditions of high temperatures and humidity should be avoided, and storage bags should be sealed to avoid contact with the air to the extent possible.

3) Finally, we found that significant quantities of carbon dioxide were generated under sufficiently moist conditions, even for low-temperature storage. The largest amount of carbon dioxide was generated (and reached lethal levels) when the SSSR and Fish meal were stored in a closed environment at temperatures around $30{ }^{\circ} \mathrm{C}$. To prevent accidents due to oxygen deficiency and to protect the health of the workers, we advise measuring the oxygen concentration of the storage area with an oximeter that can be read from outside the storage area. In this way, the safety of the storage area may be verified before entering.

\section{References}

Fu, Z. M., Li, X. R., \& Koseki, H. (2005) Heat generation of refuse derived fuel with water. Journal of Loss Prevention in the Process Industries, 18, 27-33. http://dx.doi.org/10.1016/j.jlp.2004.09.001

Hoshino,T., Iwata, Y., \& Koseki, H. (2007). Oxidation Stability and Risk Evaluation of Biodisel. Thermal Science, 11, 2, 87-100. http://dx.doi.org/10.2298/TSCI0702087H

Koseki, H. (2011) Evaluation of Various Solid Biomass Fuels Using Thermal Analysis and Gas Emission Tests. Energies, 4, 616-627. http://dx.doi.org/10.3390/en4040616

Li, X. R., Koseki, H., \& Momota, M.(2006) Evaluation of danger from fermentation-induced Spontaneous ignition of wood chips. Journal of Hazardous Materials, 135(1-3), 15-20. http://dx.doi.org/10.1016/j.jhazmat.2005.11.034

Li, X. R., Koseki, H., \& Iwata, Y. (2008) Risk Assessment on Processing Facility of Raw Organic Garbage. Journal of Hazardous Materials, 154(1-3), 38-43. http://dx.doi.org/10.1016/j.jhazmat.2007.09.109

Li, X. R.,Koseki, H., Iwata, Y., \& L, W. S. (2008) Thermal behavior of sewage sludge derived fuels. Thermal Science, 12(2), 137-148. http://dx.doi.org/10.2298/TSCI0802137L

Shibata, Y., Koseki, H., \& Shimizu, O. (2008) Spontaneous ignition of biodiesel: A potential fire risk. Thermal Science, 12: 149-158. http://dx.doi.org/10.2298/TSCI0802149S

Wada, O. (2006). Manual of Occupational Health. Nanzando, 202-203.

Table 1. Mass loss at $100^{\circ} \mathrm{C}$ and heat-generation-onset temperature

\begin{tabular}{|c|c|c|}
\hline Sample & $\begin{array}{c}\text { Mass loss } \\
\text { at } 100{ }^{\circ} \mathrm{C}(\%)\end{array}$ & $\begin{array}{c}\text { Heat generation } \\
\text { onset temperature }\left({ }^{\circ} \mathrm{C}\right)\end{array}$ \\
\hline SSSR & 25.6 & 172.9 \\
\hline Fish meal & 7.8 & 187.3 \\
\hline
\end{tabular}


Table 2. Heat generation onset temperature and total heat generated for SSSR (room temperature to $100{ }^{\circ} \mathrm{C}$ )

\begin{tabular}{|c|c|c|}
\hline Sample & $\begin{array}{c}\text { Heat generation onset } \\
\text { temperature }\left({ }^{\circ} \mathrm{C}\right)\end{array}$ & Total heat generation $(\mathrm{J} / \mathrm{g})$ \\
\hline SSSR & 27.8 & 12.9 \\
\hline EOG treated SSSR & 53.8 & 10.8 \\
\hline Defatted SSSR & 55.1 & 10.3 \\
\hline
\end{tabular}

Table 3. Heat generation onset temperature and total heat generated for Fish meal (room temperature to $100{ }^{\circ} \mathrm{C}$ )

\begin{tabular}{|c|c|c|}
\hline Sample & $\begin{array}{c}\text { Heat generation onset } \\
\text { temperature }\left({ }^{\circ} \mathrm{C}\right)\end{array}$ & Total heat generation $(\mathrm{J} / \mathrm{g})$ \\
\hline Fish meal & 41.2 & 13.2 \\
\hline EOG treated Fish meal & 42.3 & 12.9 \\
\hline Defatted Fish meal & 51.3 & 11.9 \\
\hline
\end{tabular}

Table 4. GC results for SSSR ( 5 to $50^{\circ} \mathrm{C}$ )

\begin{tabular}{|c|c|c|c|c|c|}
\hline \multirow{2}{*}{ Sample name } & \multirow{2}{*}{$\begin{array}{l}\text { Storage } \\
\text { Period }\end{array}$} & \multirow{2}{*}{$\begin{array}{c}\text { Storage } \\
\text { Temperature }\end{array}$} & \multicolumn{3}{|c|}{ GC Analysis Results (\%) } \\
\hline & & & $\mathrm{O}_{2}$ & $\mathrm{~N}_{2}$ & $\mathrm{CO}_{2}$ \\
\hline SSSR & \multirow{12}{*}{10 days } & \multirow{2}{*}{$5^{\circ} \mathrm{C}$} & 18.57 & 77.39 & 1.25 \\
\hline $\begin{array}{c}\text { SSSR } \\
+ \\
\text { Distilled water } 20 \%\end{array}$ & & & 12.33 & 77.78 & 5.83 \\
\hline SSSR & & \multirow{2}{*}{$15^{\circ} \mathrm{C}$} & 16.21 & 78.76 & 2.35 \\
\hline $\begin{array}{c}\text { SSSR } \\
+ \\
\text { Distilled water } 20 \%\end{array}$ & & & 5.32 & 79.32 & 15.31 \\
\hline SSSR & & \multirow{2}{*}{$25^{\circ} \mathrm{C}$} & 1.71 & 79.38 & 16.08 \\
\hline $\begin{array}{c}\text { SSSR } \\
+ \\
\text { Distilled water } 20 \%\end{array}$ & & & 1.66 & 79.12 & 18.19 \\
\hline SSSR & & \multirow{2}{*}{$30^{\circ} \mathrm{C}$} & 1.65 & 81.20 & 16.55 \\
\hline $\begin{array}{c}\text { SSSR } \\
+ \\
\text { Distilled water } 20 \%\end{array}$ & & & 1.54 & 79.63 & 18.22 \\
\hline SSSR & & \multirow{2}{*}{$40^{\circ} \mathrm{C}$} & 2.13 & 79.20 & 15.31 \\
\hline $\begin{array}{c}\text { SSSR } \\
+ \\
\text { Distilled water } 20 \%\end{array}$ & & & 0.89 & 80.28 & 16.43 \\
\hline SSSR & & \multirow{2}{*}{$50^{\circ} \mathrm{C}$} & 12.76 & 80.22 & 5.62 \\
\hline $\begin{array}{c}\text { SSSR } \\
+ \\
\text { Distilled water } 20 \%\end{array}$ & & & 10.23 & 78.90 & 7.53 \\
\hline
\end{tabular}


Table 5. GC results for Fish meal $\left(5\right.$ to $\left.50{ }^{\circ} \mathrm{C}\right)$

\begin{tabular}{|c|c|c|c|c|c|c|c|}
\hline \multirow{2}{*}{ Sample name } & \multirow{2}{*}{$\begin{array}{c}\text { Storage } \\
\text { Period }\end{array}$} & \multirow{2}{*}{$\begin{array}{c}\text { Storage } \\
\text { Temperature }\end{array}$} & \multicolumn{5}{|c|}{ GC Analysis Results (\%) } \\
\hline & & & $\mathrm{O}_{2}$ & $\mathrm{~N}_{2}$ & $\mathrm{H}_{2}$ & $\mathrm{CO}$ & $\mathrm{CO}_{2}$ \\
\hline Fish meal & & & 20.42 & 76.67 & - & - & 0.04 \\
\hline $\begin{array}{c}\text { Fish meal } \\
+ \\
\text { Distilled water } 20 \%\end{array}$ & & $5^{\circ} \mathrm{C}$ & 19.62 & 77.13 & - & - & 0.13 \\
\hline Fish meal & & & 20.30 & 76.82 & - & - & 0.04 \\
\hline $\begin{array}{c}\text { Fish meal } \\
+ \\
\text { Distilled water } 20 \%\end{array}$ & & $15^{\circ} \mathrm{C}$ & 18.65 & 77.46 & - & - & 0.57 \\
\hline Fish meal & & & 20.11 & 77.42 & 0.0006 & 0.003 & 0.49 \\
\hline $\begin{array}{c}\text { Fish meal } \\
+ \\
\text { Distilled water } 20 \%\end{array}$ & 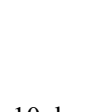 & $25^{\circ} \mathrm{C}$ & 3.95 & 83.31 & 0.0010 & 0.014 & 11.60 \\
\hline Fish meal & & & 14.28 & 81.26 & 0.0025 & 0.050 & 0.85 \\
\hline $\begin{array}{c}\text { Fish meal } \\
+ \\
\text { Distilled water } 20 \%\end{array}$ & & $30^{\circ} \mathrm{C}$ & 3.47 & 82.10 & 0.0058 & 0.0073 & 12.34 \\
\hline Fish meal & & & 16.06 & 79.70 & 0.0029 & 0.0406 & 0.62 \\
\hline $\begin{array}{c}\text { Fish meal } \\
+ \\
\text { Distilled water } 20 \% \\
\end{array}$ & & $40 \mathrm{C}$ & 5.67 & 80.52 & 0.0293 & 0.0714 & 10.55 \\
\hline Fish meal & & & 17.21 & 79.22 & 0.0058 & 0.1491 & 0.54 \\
\hline $\begin{array}{c}\text { Fish meal } \\
+ \\
\text { Distilled water } 20 \%\end{array}$ & & $50 \mathrm{C}$ & 6.88 & 80.23 & 0.0069 & 0.2061 & 8.53 \\
\hline
\end{tabular}

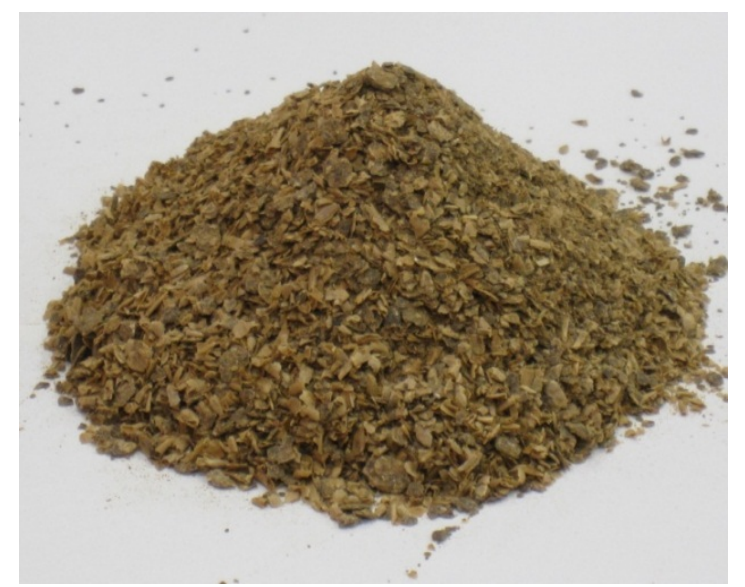

Figure 1. Soy sauce squeezing residue (SSSR) 


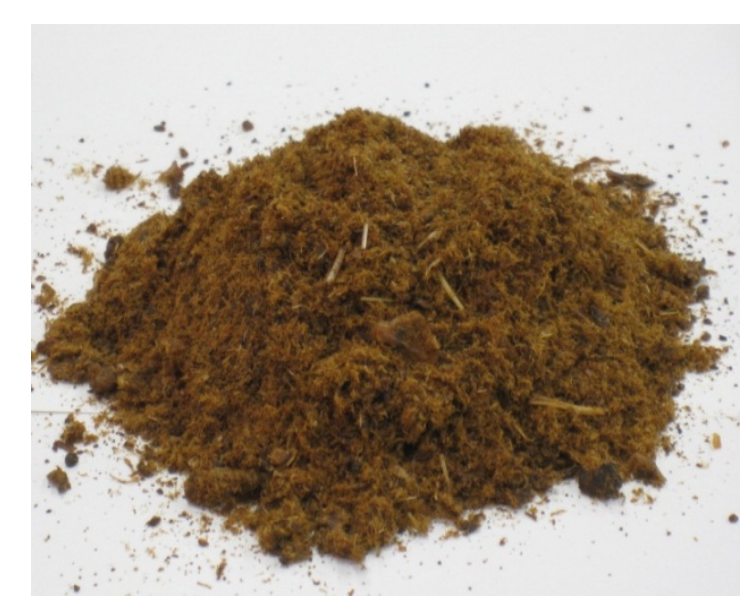

Figure 2. Fish meal

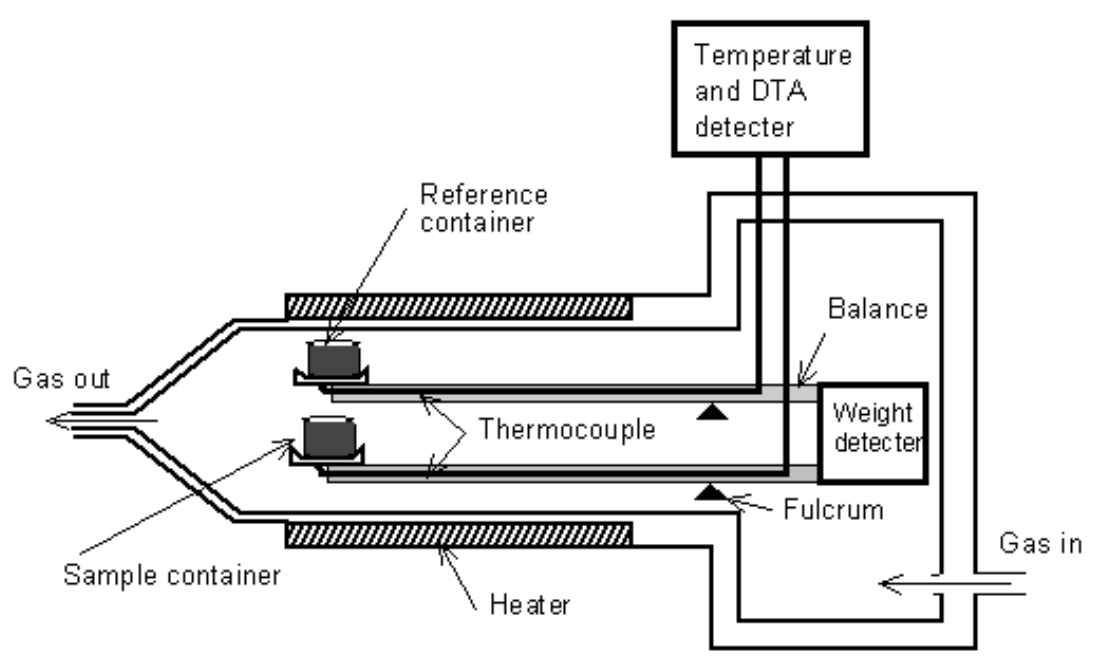

Figure 3. Schematic of TG-DTA

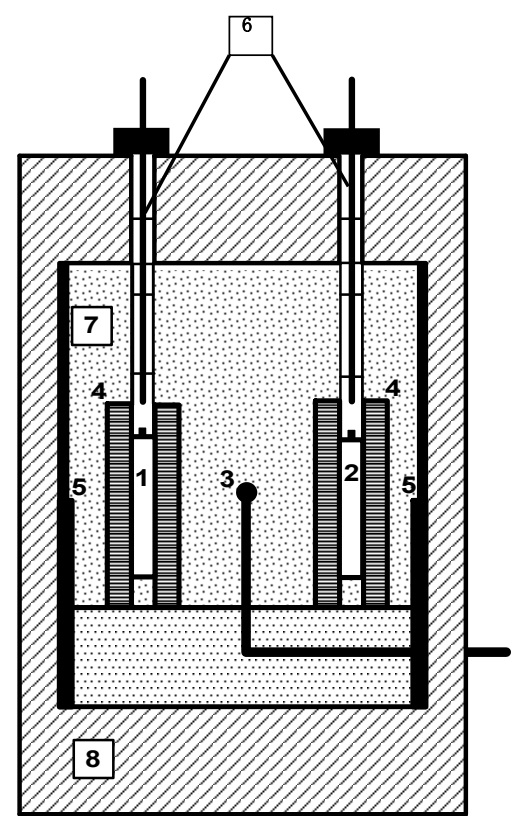

1: Reference vessel

2: Sample vessel

3: Thermostat

4: Heat-flow detector

5: Heaters

6: Insulating space

7: Calorimetric block

8: Insulating material

Figure 4. Schematic of C80 


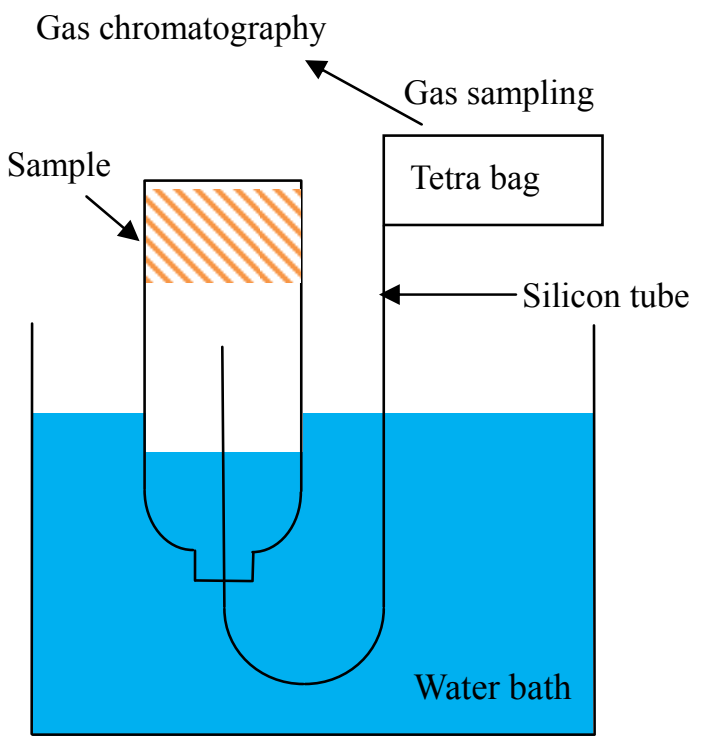

Figure 5. Schematic of gas chromatography measuring device

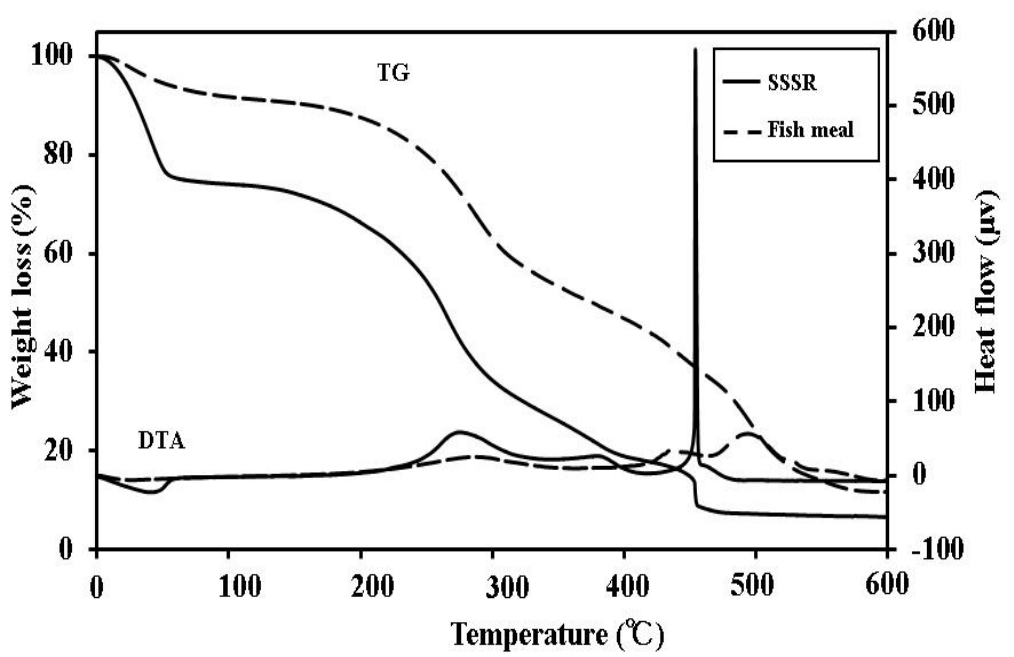

Figure 6. TG-DTA results for SSSR and Fish meal ( $2 \mathrm{~K} / \mathrm{min})$

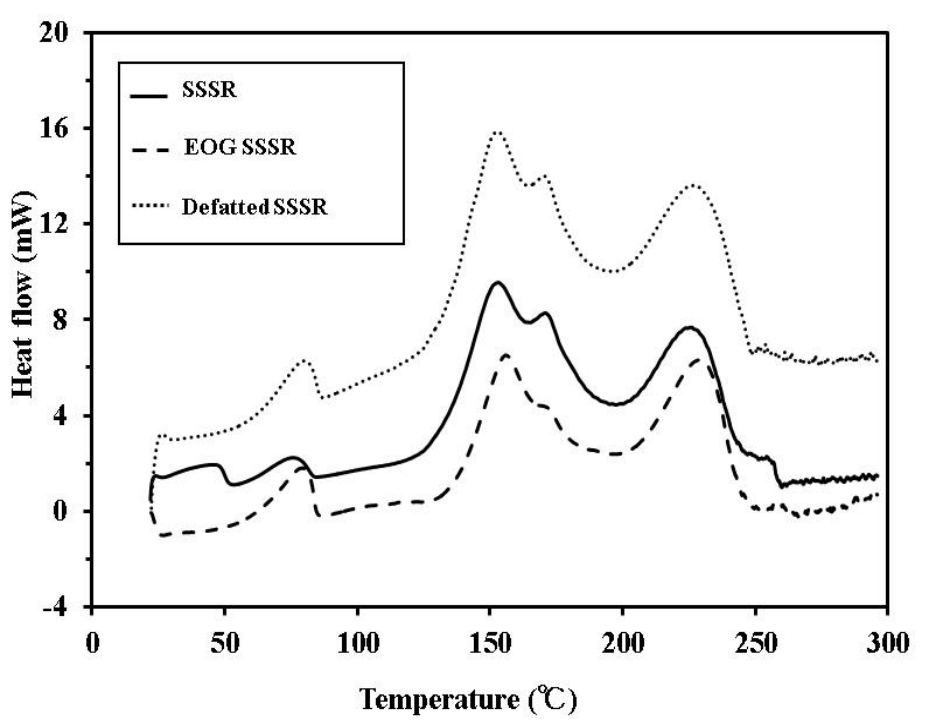

Figure 7. C80 results for SSSR $(0.1 \mathrm{~K} / \mathrm{min})$ 


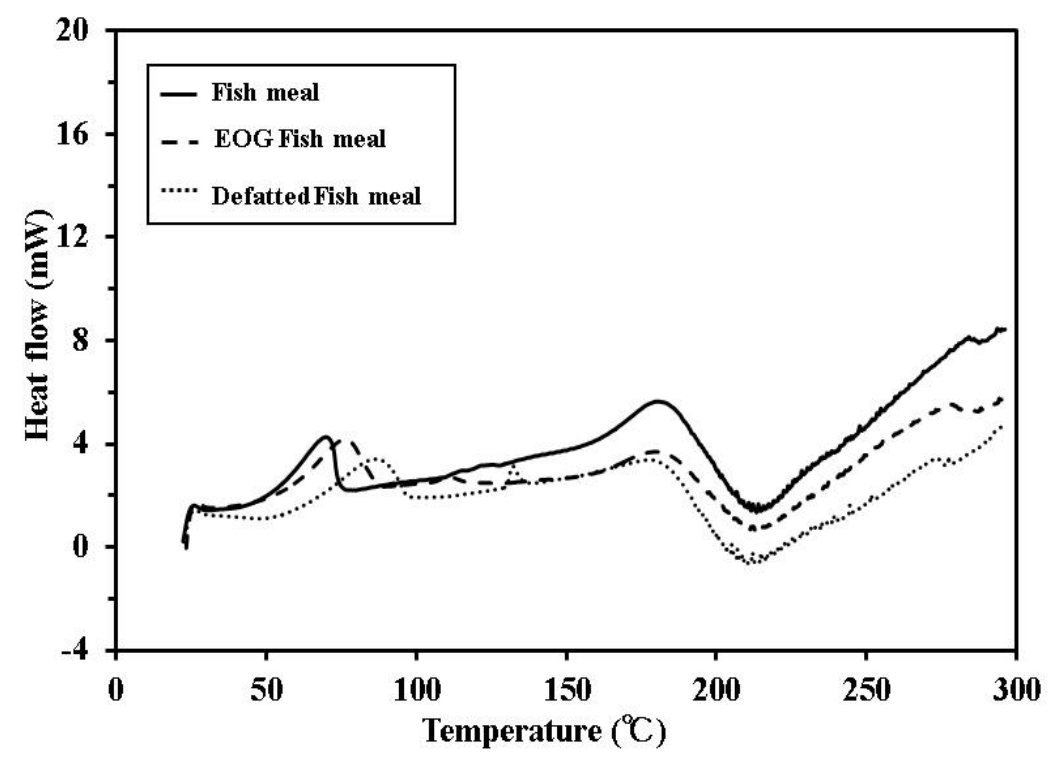

Figure 8. C80 results for Fish meal $(0.1 \mathrm{~K} / \mathrm{min})$

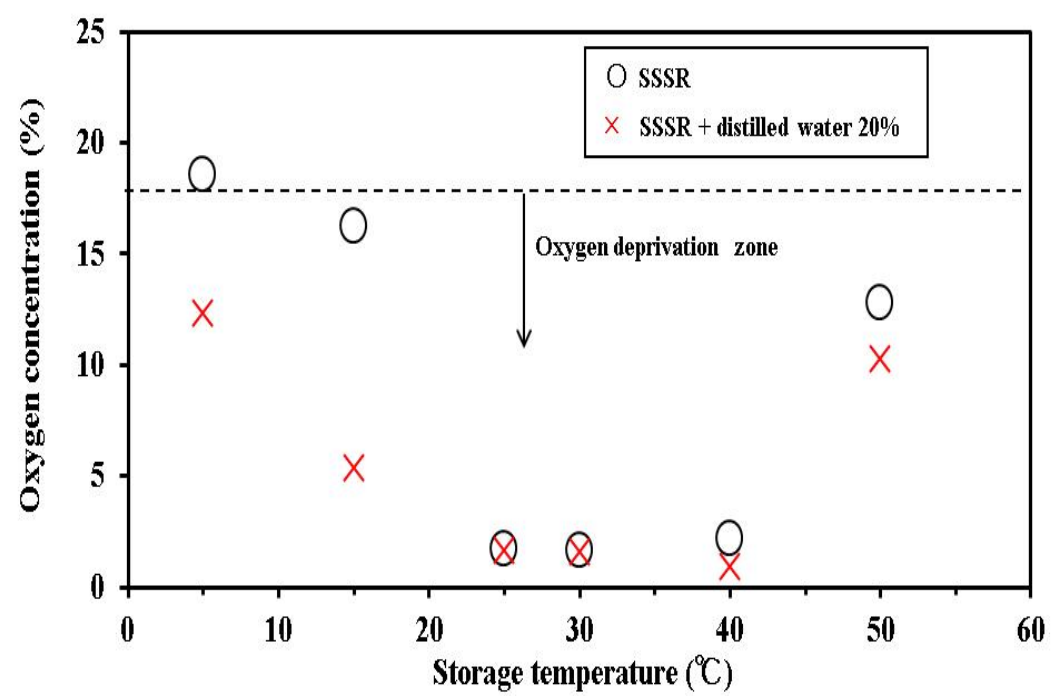

Figure 9.Correlation between storage temperature and oxygen concentration (SSSR)

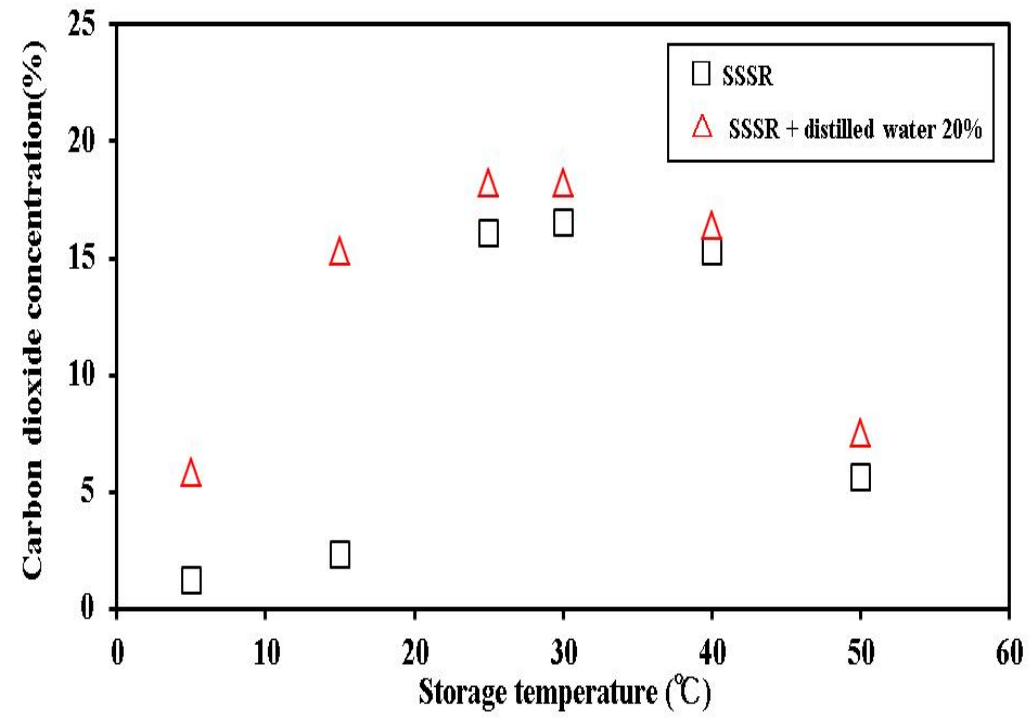

Figure 10. Correlation between storage temperature carbon dioxide concentration (SSSR) 


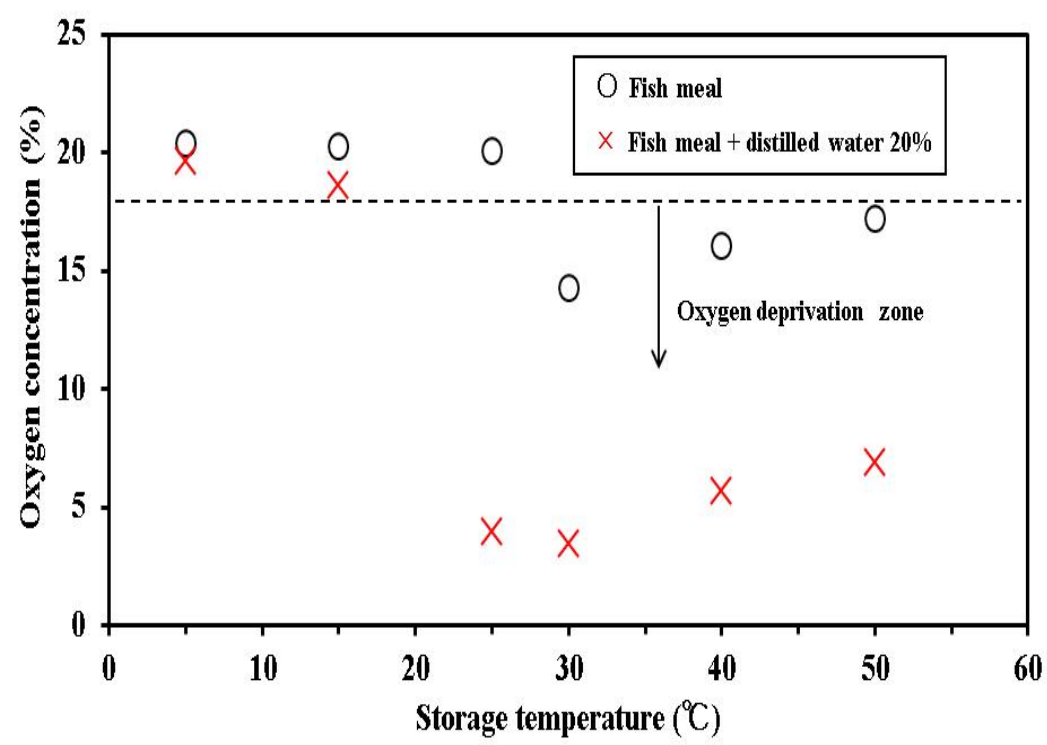

Figure 11. Correlation between storage temperature and oxygen concentration (Fish meal)

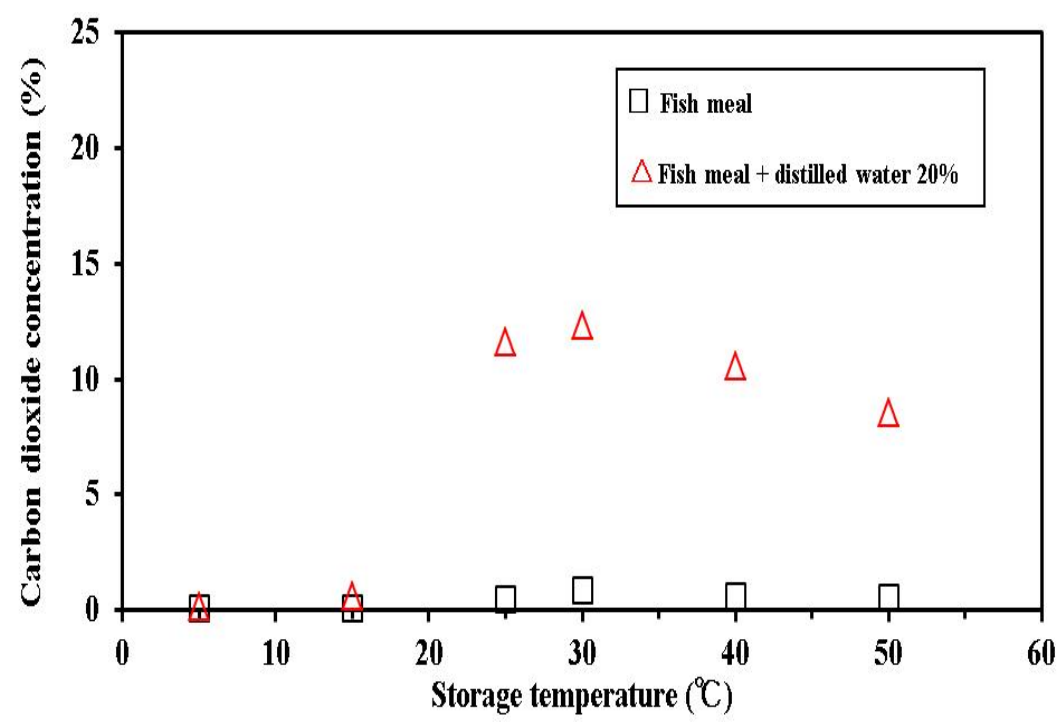

Figure 12. Correlation between storage temperature and oxygen concentration (Fish meal). and carbon dioxide concentration (Fish meal) 